\section{Jubilee of the Discovery of the Electron}

IN Nature of December 6, p. 776, an account was given of celebrations in London arranged by the Institute of Physics, the Physical Society, and the Institution of Electrical Engineers to mark the jubilee of the discovery of the electron by Sir J. J. Thomson in 1897. It is of interest to learn that the event was also remembered on the Continent. The Bernische Naturforschende Gesellschaft held a commemorative meeting in June 1947, with Dr. A. Kurz in the chair. An address was delivered by Prof. André Mercier ; as a professor of theoretical physics, he insisted especially on the great influence that the discovery of the electron has had since 1897 on physical theories, particularly under the impulse given by H. A. Lorentz, W. Pauli and P. A. M. Dirac.

\section{Institute of Metals : Elections}

The Council of the Institute of Metals has made the following elections: Fellows (members who have rendered eminent service to the Institute), Dr. C. H. Desch, formerly superintendent of the Metallurgy Division, National Physical Laboratory; Sir John Greenly, chairman of the British Non-Ferrous Metals Research Association and a past-president of the Institute of Metals. Honorary Members (in recognition of their distinguished services to the science or practice of non-ferrous metallurgy), Prof. P. A. J. Chevenard, member of the Institut de France, known for his work on special steels; Sir Geoffrey Taylor, Yarrow research professor of the Royal Society; Dr. J. F. Thompson, executive vice-president of the International Nickel Company of Canada, Ltd., known for his studies of the science and practice of non-ferrous metallurgy.

Ministries of Food and Health: Lasker Group Award

A Lasker Group Award for 1947 has been presented by the American Public Health Association to the British Ministries of Food and Health "for the unprecedented programme of food distribution in Great Britain" during the War, "with resulting improvement in the health of the people". The Lasker Award, which takes the form of a statuette of the "Winged Victory of Samothrace", was provided through the generosity of the Albert and Mary Lasker Foundation, and is made either to individuals for their achievement in the field of medical research and public health administration or to groups for outstanding work or research. This is the first occasion on which the award has been given outside the United States.

\section{Nuffield (Penicillin) Research Fellowships}

LORD NUFFIELD has given $£ 50,000$ to Lincoln College, Oxford, of which Sir Howard Florey is a fellow, to establish three research fellowships in science and allied medicine. The gift is to commemorate the discovery, in the Sir William Dunn School of Pathology, of which Sir Howard Florey is head, of the chemotherapeutic properties of penicillin. The fellowships are to be known as Nuffield (Penicillin) Research Fellowships.

\section{University of Glasgow}

THe following appointments in the University of Glasgow have been announced: Prof. Thomas Alty, Cargill professor of natural philosophy, deputy principal; Dr. Basil C. King, lecturer in geology; Messrs. Daniel Martin and Walter Brown, lecturers in mathematics; Messrs. John B. Birks (formerly an I.C.I. Fellow) and G. M. Lewis (from University College, Hull), lecturers in natural philosophy; and (from April 1, 1948) Dr. William C. Hutchison, lecturer in physiology in the University of Edinburgh, and Mr. George Leaf (from the National Institute for Medical Research), lecturers in physiological chemistry.

For the 1947-48 session, 350 students have been admitted to the various first-year classes covered by the Faculty of Science-280 in pure science and 70 in applied. These numbers represent a slight reduction compared with the 1946-47 session. Of the 250 fresh admissions, about 45 per cent are ex-Servicemen. Of the graduate research students who have been registered, or re-registered, about sixty are at the University and forty at the Royal Technical College, Glasgow.

\section{University of Leeds : Appointments}

THE following appointments in the University of Leeds have been announced: Dr. W. Bradley (at present research director at the British Drug Houses, Ltd.), professor of colour chemistry and dyeing, in succession to the late Prof. F. M. Rowe; Mr. A. H. Hanson, lecturer in the Departments of Social Studies and Extra-Mural Studies; Mr. H. D. Ursell, lecturer in mathematics, to succeed Mr. R. M. Gabriel as reader in mathematical analysis.

\section{University of Sheffield: Appointments}

THE following appointments in the University of Sheffield have been announced: Dr. S. R. Elsden, senior lecturer in microbiology in the Department of Bacteriology ; R. O'Rahilly, lecturer in anatomy ; T. F. Bamber (at present research assistant), assistant lecturer in the Department of Mining; Dr. J. L. Emery, honorary lecturer in pathology.

\section{Agricultural Research Council: Postgraduate Scholarships}

THE Agricultural Research Council announces the following awards of postgraduate scholarships in agricultural science and in animal health, to be held at the university or college mentioned from the beginning of the academic year 1947: P. Aitkenhead (Durham), a two-year research scholarship in entomology ; N. Bateman (London), a three-year research scholarship in animal genetics; J. R. Butler (Cambridge), a three-year research scholarship in soil mineralogy ; J. W. B. King (Cambridge), a three-year research scholarship in animal genetics; D. Lewis (Wales), a three-year scholarship in biochemistry; A. M. McCallum (Glasgow Veterinary College), a one-year research scholarship in animal health; I. A. Nicholson (Durbam), a three-year research scholarship in plant breeding; H. Platt (Liverpool), a one-year research scholarship in animal pathology; Miss P. E. Stokes (London), a threeyear research scholarship in plant physiology; K. F. Thompson (Cambridge), a three-year research scholarship in plant genetics; G. M. Urquhart (Glasgow Veterinary College), a one-year research scholarship in animal parasitology; D. P. Webley (Durham), a one-year research scholarship in entomologv ; Miss J. N. Winfield (Leeds), research scholarship in plant pathology renewed for one further year from October 1, 1947.

\section{Type Cultures of Fungi}

I From January 1, the National Collection of Type Cultures preserved by the Lister Institute has 